\title{
Radiotherapy in the Treatment of High Volume Chylous Fistula Following Hepatectomy: Case Report and Review of the Literature
}

\author{
Hepatektomi Sonrasında Gelișen Yüksek Debili Șilöz Fistül Tedavisinde Radyoterapi: \\ Olgu ve Literatür Sunumu
(D) Osman Nuri Dilek1, (D) Ayhan Aydın², (D) Turan Acar1, (D) Cengiz Tavusbay¹, (D) Emine Özlem Gür¹, (D) Salih Can Çelik¹, (D) Hüseyin Sinan Akay33, (D) Mehmet Hacıyanlı1

${ }^{1}$ Katip Çelebi University, Atatürk Training and Research Hospital, Clinic of General Surgery, İzmir, Turkey

${ }^{2}$ Katip Celebi University, Atatürk Training and Research Hospital, Clinic of Radiation Oncology, İzmir, Turkey

${ }^{3}$ Katip Çelebi University, Atatürk Training and Research Hospital, Clinic of Gastroenterology, İzmir, Turkey

\begin{abstract}
Lymphatic injury is common in surgical procedures, but only $1-11 \%$ of cases present with chylous fistula. Although high volume chylous fistula is a rare condition after liver resection, serious life-threatening complications such as empyema and peritonitis secondary to severe mechanical, nutritional and immunological disorders due to protein loss may accompany this condition. Here, we report a 58-year-old male patient with Klatskin tumor (Bismuth-Corlette, 3A) who had high volume chylous fistula after right hepatectomy. In spite of medical treatment (fat-free diet, somatostatin) and tube drainage for 4 weeks, daily chylous fistula ranged between 600-1800 cc/day. Due to the prolonged drainage, low-dose radiotherapy was applied to the patient. The patient underwent fractionated radiotherapy protocol at a daily dose of 150 cGy (total 1200 cGy) for 8 days. The drainage decreased to 150 cc on day 1 , than to 50 cc on day 3 and the drain was removed on day 5 . The patient has been under follow up without any problem for 18 months. Several interventional and surgical multimodal procedures have been described in the literature for the treatment of refractory chylous fistulas. There are very few studies on radiotherapy in the literature. We believe that low-dose fractionated radiotherapy may be an alternative treatment modality for refractory cases.
\end{abstract}

Keywords: Chylous fistula, complication, hepatectomy, liver, radiotherapy

\section{öZ}

Lenfatik yaralanma cerrahi girişimler sırasında sıklıkla olmakla birlikte, olguların \%1-11'inde şilöz fistül olarak karşımıza çıkmaktadır. Karaciğer rezeksiyonları sonrasında yüksek debili șilöz fistül nadiren görülen bir durum olmakla beraber, protein kaybına bağlı olarak ortaya çıkan ciddi mekanik, nütrisyonel ve immünolojik bozukluklar sonucunda ampiyem ve peritonit gibi yaşamı tehdit eden ciddi komplikasyonlar tabloya eșlik edebilir.

Burada, 58 yaşındaki Klatskin tümörlü (Bismuth-Corlette, 3A) bir erkek hastamızda yaptığımız sağ hepatektomi sonrasında ortaya çıkan yüksek debili bir șilöz fistül olgusu sunulmuștur. Yapılan 4 haftalık tıbbi (yağdan fakir diyet, somatostatin) tedaviye ve tüp drenaja rağmen günlük şilöz fistülün 6001800 cc/gün arasında değişerek devam ettiği gözlendi. Sürecin uzaması nedeniyle, hastaya düşük doz radyoterapi uygulamasının yapılmasına karar verildi. Hastaya günlük 150 cGy fraksiyone dozda 8 günlük radyoterapi protokolü (toplam 1200 cGy) uygulandı. Uygulama sonrası 1. günde drenaj miktarı 150 cc'ye ve sonraki 3 günde toplam 50 cc'ye indi ve dren çekildi. Hasta post-operatif 18 aydır problemsiz izlenmektedir.

Literatürde medikal tedaviye dirençli şilöz fistüllerin tedavisi amacıyla girişimsel ve cerrahi pek çok multimodal prosedür tanımlanmıştır. Tedavide radyoterapi uygulaması ile ilgili çalıșmalar ise çok azdır. Olgumuzda uyguladığımız düşük doz farksiyonize radyoterapi uygulamasının tedaviye dirençli olgularda alternatif bir tedavi yöntemi olabileceğine inanıyoruz.

Anahtar Kelimeler: Șilöz fistül, komplikasyon, hepatektomi, karaciğer, radyoterapi
Address for Correspondence/Yazıșma Adresi: Osman Nuri Dilek, Katip Çelebi University, Atatürk Training and Research Hospital, Clinic of General Surgery, İzmir, Turkey

Phone: +90232 2434343 E-mail: osmannuridilek@gmail.com ORCID ID: orcid.org/0000-0002-6313-3818

Cite this article as/Atıf: Dilek ON, Aydın A, Acar T, Tavusbay C, Gür EÖ, Çelik SC, Akay HS, Hacıyanlı M. Radiotherapy in the Treatment of High Volume Chylous Fistula Following Hepatectomy: Case Report and Review of the Literature. İstanbul Med J 2019; 20(2): 152-5.

(C) Copyright 2019 by the Istanbul Training and Research Hospital/Istanbul Medical Journal published by Galenos Publishing House.

(C) Telif Hakkı 2019 İstanbul Ĕgitim ve Araștırma Hastanesi/Istanbul Tıp Dergisi, Galenos Yayınevi tarafından basılmıștır.
Received/Geliș Tarihi: 05.09.2017 Accepted/Kabul Tarihi: 05.06.2018 


\section{Introduction}

Approximately 2.4 liters of lymphatic fluid rich in fat $(0.4-6 \mathrm{~g} / \mathrm{dL})$ is absorbed from the intestines and is introduced into the circulation by lymphatic channels. Sixty to seventy percent of this transport occurs through thoracic duct. There are immunoglobulins, enzymes, digested products and leukocytes (400-6800 white blood cell/mL), mostly lymphocytes, in lymphatic fluid (1).

Chylous fistula was first described in the $17^{\text {th }}$ century after trauma (1). Lymphatic injury is seen in the neck, thoracic and intraabdominal surgery, however, only $1-11 \%$ of cases present with chylous fistula (2). Nowadays, it is seen more due to increased number of extended radical surgeries. In order to be able to call a fistula, the triglyceride value should be more than $110 \mathrm{mg} / \mathrm{dL}$ in the biochemical analysis of the collected fluid $(1,3)$. Depending on the volume in cases with fistula, serious complications such as fluid-electrolyte-protein imbalance, malnutrition, acidosis, impaired immune functions, prolonged hospital stay and infection may occur (2).

The classical approach in patients with chylous fistulas includes diet control (high protein, low fat, medium-chain triglyceride diet), fasting, somatostatin administration, parenteral fluid supplementation and total parenteral nutrition $(1,2,4,5)$. In case of increased volume of chylous fistula and prolonged drainage, the risk of morbidity increases and the stabilization of the patient becomes more difficult. Several interventional and surgical treatment methods have been described in the literature for patients refractory to medical treatment (Table 1) $(1,2)$. Despite all interventions, the surgical approach may also fail in the treatment of refractory cases with high volume. There are some studies reporting that approximately half of the patients can die due to complications $(1,2,6)$.

There are several studies on the development of chylous acid or chylothorax after radiotherapy or exposure to radiation. However, there are few studies on the use of radiotherapy in the treatment of chylous fistula $(1,2,5,6)$.

Here, we present a refractory high volume chylous fistula case that was successfully treated by radiotherapy, and discuss the topic in the light of the literature.

\section{Case Report}

The serous drainage started on post-operative day 5 in a 58-year-old male patient who underwent right hepatectomy for Klatskin tumor (Bismuth-Corlette, 3A) and increased from 300-700 cc to 1100 cc on day 7 with becoming a milky-white fluid rich in fats. Biochemical analysis of drain fluid confirmed chylous fistula (triglycerides $>110 \mathrm{mg} / \mathrm{dL}$ ). In spite of medical treatment (fasting, diet, somatostatin and parenteral fluid therapy) for 4 weeks, daily chylous fistula ranged between 600$1800 \mathrm{cc} /$ day (Figure 1). There was no improvement despite all the classical medical treatment modalities. Due to the prolonged drainage, the radiotherapy treatment protocol was decided to be applied earlier. Informed consent was obtained from the patient and radiotheraphy was initiated. The patient underwent an 8-day low-dose fractionated radiotherapy protocol at a daily dose of $150 \mathrm{cGy}$ (total $1200 \mathrm{cGy}$ ) starting from post-operative day 28 (Figure 2). The drainage decreased to $150 \mathrm{cc}$ on day 1, than to 50 cc on day 3 and the drain was removed. Therapeutic radiotherapy was completed and liver functions of the patient were normal. He was discharged without any problems and the patient has been under follow up without any problem for 18 months.

\section{Discussion}

Chylous ascites may develop due to traumatic and atraumatic causes. Intraabdominal tumors (17-57\%), anomalies (32\%), cirrhosis (11\%) and mycobacterial infections (10\%) are the most common atraumatic medical causes $(2,5)$. Studies have shown that lymph node dissection and the number of lymph nodes, tumors fed from the superior mesenteric artery, retroperitoneal tumor invasion, paraaortic region dissection, surgeon's experience, radical surgical procedures, chronic pancreatitis, hypoalbuminemia, neoadjuvant chemotherapy and early enteral nutrition may play a role in the development of chylous acid $(1,2,7)$.

It is common for the lymphatic structures to be traumatized during surgical procedures and they recover spontaneously in most cases. There are very few cases reported after liver surgery. It can be seen especially after transplantation and major liver surgery. In their study including 516 liver transplantation cases, Yılmaz et al. (3) stated that 24 cases (4.6\%) had chylous acid. In the same study, hypoalbuminemia, presence of acid, hilar zone dissection and using vessel sealing system have been reported to increase the risk (3). In a systematic analysis performed by Weniger et al. (2), chylous acid was observed in $4.7 \%$ of liver surgeries, $1-11 \%$ of pancreatic surgeries, $1-6.6 \%$ of colorectal surgeries and $11.5 \%$ of gastric tumor surgeries with D3 lymph node dissection. The location of the pathology can be detected by lymphangiography in $75 \%$ of cases $(2,8,9)$. In our case, it was thought that chylous fistula developed after extensive hilar and lymphatic dissections performed for right hepatectomy for hilar cholangiocarcinoma. However, no localization study was performed in our case.

The clinical case series related to the treatment of chylous acid or fistula are limited and there are no treatment guidelines and algorithms (2). Most of the chylous fistula cases (77\%-100\%) recover with the classic medical approach $(1,2,5)$. We applied the classical approach modalities in our patient for four weeks, but we failed. Various and more aggressive modalities are applied in cases with inadequate response to treatment (Table 1). In addition to the aforementioned treatments for chylous acid in cases without drain, there are also case seies with intermittent paracentesis. Diuretics have no place in treatment. Although there were literature data on the use of orlistat, we did not use it $(1,5)$.

Application of local chemical sclerosing agents and embolization with lymphangiography are the treatment options that should be considered before surgery for the refractory cases. Matsumoto et al. (10) treated 8 of 9 cases with lymphangiography. Shunt surgery (Le Veen or Denver) or ligation of open lymphatic ducts are the other recommended treatment methods $(1,11)$. In a series of 163 cases with complex oncologic surgical procedures, Kaas et al. (12) reported that 12 cases (7.4\%) had chylous acid and nine of them recovered with conservative treatment, and that they applied peritoneovenous shunting in three cases. However, there are also studies reporting that shunts should be revised frequently and that $20 \%$ of the cases have died (13). 


\begin{tabular}{|c|c|}
\hline \multirow{5}{*}{ Medical } & - Enteral nutrition/TPN (Total parenteral nutrition) \\
\hline & - Fat restriction on diet \\
\hline & - Octreotide, $300 \mu \mathrm{g} / \mathrm{day}$ \\
\hline & - Orlistat (Reversible lipaz inhibitor) \\
\hline & - Etilefrine (Sympathomimetic), $120 \mathrm{mg} /$ day \\
\hline \multirow{7}{*}{ Interventional } & - Paracentesis \\
\hline & $\begin{array}{l}\text { - Pleurodesis/Peritoneodesis (Talc, tetracyclin, fibrin glue, } \\
\text { concentrated glucose solution, streptokinase, OK-432...) }\end{array}$ \\
\hline & - Percutaneous drainage \\
\hline & - TIPS (Transjugular intrahepatic portosystemic shunts) \\
\hline & - Lymphangiography \\
\hline & $\begin{array}{l}\text { - Embolization of lymph ducts (Cysterna chyle } \\
\text { embolization) }\end{array}$ \\
\hline & - Low-dose radiotherapy application \\
\hline \multirow{4}{*}{ Surgical } & -Abdominal drainage \\
\hline & -Pleuroperitoneal shunt \\
\hline & -Peritoneovenous shunt \\
\hline & -Ligation of Cysterna chyle (Open/Laparoscopic) \\
\hline
\end{tabular}

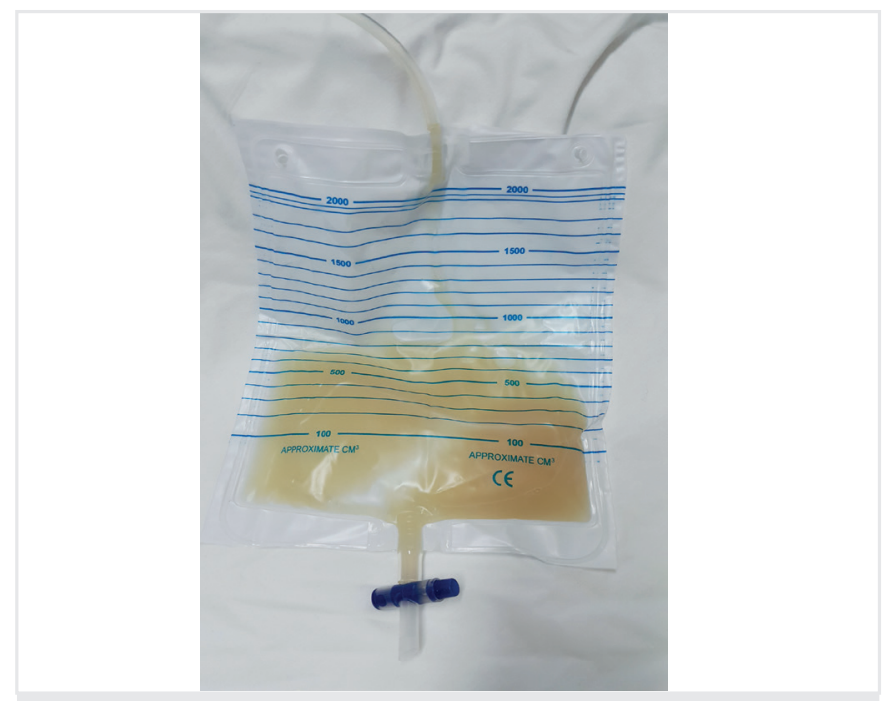

Figure 1. The chylous fistula volume from the subhepatic drainage varies between 600-1800 cc per day

Sensitivity of the lymphatic tissue to radiation is known. It is known that chylous acid may develop due to radiotherapy. On the other hand, it is also known that edema occurs in the lymphatic tissue primarily, followed by narrowing of the canals and decrease in lymphatic tissue size. There are very few publications in the literature on this subject (1,6,14-18). Dietl et al. (14) achieved successful results with low-dose radiotherapy in refractory lymphorrhea after vascular interventions in the inguinal region. Habermehl et al. (15) reported similar results. In the literature, there are studies reporting that chylous acides due to celiac lymphoma is treated by radiotherapy (14). It was reported that chylous fistula developed after gastric cancer surgery with D2 dissection was successfully treated with low-dose radiation (15). The largest series

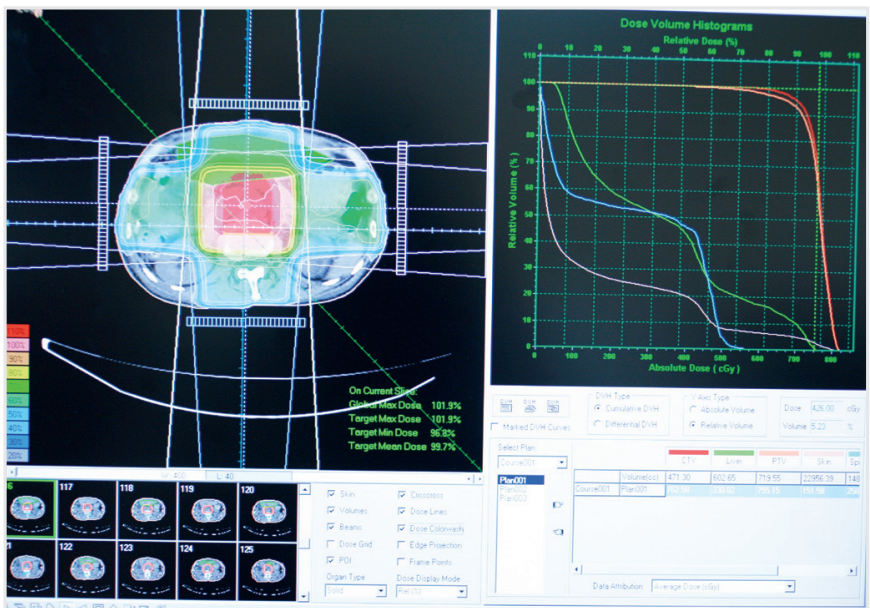

Figure 2. Radiotherapy protocol: The patient underwent an 8-day lowdose fractionated radiotherapy protocol at a daily dose of $150 \mathrm{cGy}$ (total 1200 cGy) starting from post-operative day 28

of chylous fistulas treated with a radiotherapeutic approach was by Sziklavari et al. (6) from Germany with 7 cases. The cases in this series included patients undergoing thoracotomy and lobectomy or wedge resection. Regarding the operated organ, our case is the first case treated with radiotherapy in the literature. As a result, we achieved a successful outcome in our patient with low-dose radiotherapy (Figure 1). On the $5^{\text {th }}$ day of low-dose radiotherapy, the drainage stopped and the patient has been under follow up without any problem for 18 months.

\section{Conclusion}

High volume chylous fistula is a serious complication with high morbidity and mortality. In the literature, several interventional and surgical multimodal procedures have been described for the treatment of the refractory chylous fistulas. However, there is few data about radiotherapy in the treatment. We believe that low-dose fractionated radiotherapy may be an alternative treatment modality for refractory cases.

Informed Consent: Informed consent was obtained from the patient and radiotheraphy was initiated.

Peer-review: Externally and internally peer-reviewed.

Author Contributions: Concept - O.N.D., A.A.; Design - O.N.D., A.A.; Supervision - O.N.D.; Resources - T.A., E.Ö.G.; Materials - H.S.A.; Data Collection and/or Processing - C.T., T.A.; Analysis and/ or Interpretation O.N.D., M.H.; Literature Search - T.A., S.C.C.; Writing Manuscript - O.N.D., M.H.; Critical Review - O.N.D., A.A.

Conflict of Interest: No conflict of interest was declared by the authors.

Financial Disclosure: The authors declared that this study received no financial support.

\section{References}

1. Tessier DJ, Geibel J. Chyle fistula. In: http://emedicine.medscape.com/ article/190025-overview, 2015 
2. Weniger M, D'Haese JG, Angele MK, Kleespies A, Werner J, Hartwig W. Treatment options for chylous ascites after major abdominal surgery: A systematic review. Am J Surg 2016; 211: 206-13.

3. Yılmaz M, Akbulut S, Ișık B, Ara C, Özdemir F, Aydın C, et al. Chylous ascites after liver transplantation: Incidence and risk factors. Liver Transplantation 2012; 18: 1046-52.

4. Baran M, Cakir M, Yüksekkaya HA, Arikan C, Aydin U, Aydogdu S, et al. Chylous ascites after living related liver transplantation treated with somatostatin analog and parenteral nutrition. Transplant Proc 2008; 40: 320-1.

5. Steinemann DC, Dindo D, Clavien PA, Nocito A. Atraumatic chylous ascites: Systematic review on symptoms and causes. J Am Coll Surg 2011; 212: 899905.e1-4.

6. Sziklavari Z, Allgäuer M, Hübner G, Neu R, Ried M, Grosser C, et al. Radiotherapy in the treatment of postoperative chylothorax. J Cardiothoracic Surgery 2013; 8: 72

7. Shiba H, Wakiyama S, Gocho T, Ishida Y, Misawa T, Yanaga K. A case of successful conservative treatment for chylous ascites after living-donor liver transplantation. Int Surg 2012; 97: 360-2.

8. Haberal M, Karakayali H, Moray G, Bilgin N. Surgical treatment of chylous ascites following partial living-related liver transplantation. Transpl Int 1998; 11: 327-8.

9. Kuboki S, Shimizu H, Yoshidome H, Ohtsuka M, Kato A, Yoshitomi H, et al. Chylous ascites after hepatopancreatobiliary surgery. Br J Surg 2013; 100: 5227.
10. Matsumoto T, Yamagami T, Kato T, Hirota T, Yoshimatsu R, Masunami T, et al. The effectiveness of lymphangiography as a treatment method for various chyle leakages. Br J Radiol 2009; 82: 286-90.

11. Aalami OO, Allen DB, Organ CH Jr. Chylous ascites: a collective review. Surgery 2000; 128: 761-78.

12. Kaas R, Rustman LD, Zoetmulder FA. Chylous ascites after oncological abdominal surgery: incidence and treatment. Eur J Surg Oncol 2001; 27: 187-9.

13. Evans JG, Spiess PE, Kamat AM, Wood CG, Hernandez M, Pettaway CA, et al. Chylous ascites after postchemotherapy retroperitoneal lymph node dissection: review of the M. D. Anderson experience. J Urol 2006; 176: 1463-7.

14. Dietl B, Pfister K, Aufschläger C, Kasprzak PM. Radiotherapy of inguinal lymphorrhea after vascular surgery. A retrospective analysis. Strahlenther Onkol 2005; 181: 396-400

15. Habermehl D, Habl G, Eckstein HH, Meisner F, Combs SE. Radiotherapeutic management of lymphatic fistulas: An effective but disregarded therapy option. Chirurg 2017; 88: 311-6.

16. Gerstein J, Kofahl-Krause D, Fruhauf J, Bremer M. Complete remission of a lymphoma-associated chylothorax by radiotherapy of the celiac trunk and thoracic duct. Strahlenther Onkol 2008; 184: 484-7.

17. Kim SW, Kim JH. Low-dose radiation therapy for massive chylous leakage after subtotal gastrectomy. Radiat Oncol J 2017; 35: 380-4.

18. Corradini S, Liebig S, Niemoeller OM, Zwicker F, Lamade W. Successful radiation treatment of chylous ascites following pancreatoduodenectomy. Strahlenther Onkol 2015; 191: 448-52. 